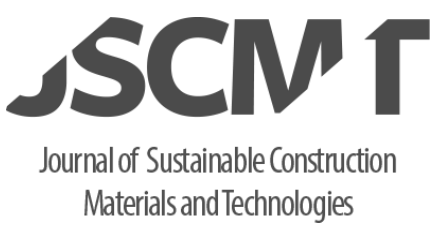

J. Sustain. Construct. Mater. Technol. 1(2) (2016) 57-59
Journal of Sustainable Construction Materials and Technologies

www.eds.yildiz.edu.tr/jscmt

\title{
Analysis of safe distance of flue from combustible construction parts in terms of fire safety in the European standards
}

\author{
Ing. Zuzana Lišková ${ }^{1, a}$, doc. Ing. Juraj Olbř́ímek, PhD. ${ }^{1, b, *}$ \\ ${ }^{1}$ STU - Stavebná fakulta, Radlinského 11, 81005 Bratislava, Slovak republic \\ azuzana.liskova@stuba.sk, bjuraj.olbrimek@stuba.sk
}

Received January 8, 2016, accepted March 20, 2016

\begin{abstract}
This topic is very actual due to the high number of chimney and flue fires, including radiators especially during the heating season. The aim of the article is to compare and assess the strictness of the regulations in selected European countries in terms of safe separation distance of the flue from the combustible construction parts.
\end{abstract}

Keywords: flue, combustible construction parts, fire safety, safe distance

\section{Introduction}

Technical development of the design of chimneys and flues was influenced by the needs of saving energy and environmental protection [1]. At present, many people returned to solid fuel heating appliances because they more and more realize the fuel efficiency and the related costs. This change brings risks, especially in the case of leaving the original flue that does not meet the requirements of the newly installed appliance.

Flues and chimneys are designed to withstand the chimney fire, which occurs during the burn out of soot. The manufacturer prescribe the fire resistance of chimney or flue in product documentation. It also provide the information about the safe separation distance from combustible products determined by examination. However, the old and historic chimneys and flues do not have determined it.

The chimney fires are one of the most common causes of fires in ressidential buildings and it can cause great damage to property, health, or even lifes. The causes of fire include burn of soot, the flue wear (failure of the compactibility), immured rafter in the chimney, inadequate separation distances from the combustible products (ceilings, floors, walls, furniture ...) improper installation or poorly maintained chimney and other failures [2].

Creosote (a mixture of soot, ash and tar) settles in the chimney by using the appliance during operating life. Burn of soot is the most common cause of all fires caused by radiators, chimneys and flues. The chimney fire occurs by ignition of flammable creosote - unburned fuel residues settled on an internal surface of chimney, which are formed by thermal decomposition of hydrocarbon compounds.

\section{Safe Separation Distance from Combustible Building Products}

\subsection{General Requirements in Slovakia.}

Flue pipes and chimneys may be installed in the direct contact (the maximum temperature rise of $52{ }^{\circ} \mathrm{C}$, or temperature class T80) or in the safe separation distance from combustible structures with the fire classification $\mathrm{B}, \mathrm{C}, \mathrm{D}, \mathrm{E}$ or F [3]. The fire classification F include materials with unspecified reaction to fire. The use of the

\footnotetext{
* Corresponding author. Tel: +421 (2) 59274450

E-mail address: azuzana.liskova@stuba.sk (Z. Lišková)
} 
products with this reaction to fire is limited in some European countries and there is a proposal for the abolition of this class.

In Decree of the Ministry of the Interior of the Slovak Republic No. 401/2007 Coll. on technical conditions and requirements for fire safety during installation and operation of fuel appliances, electric thermal appliances and central heating appliances and during construction and use of chimneys and smoke-ducts and on cleaning and inspection intervals is indicated, that the safe separation distance prescribe the manufacturer according to STN EN 1443 Chimneys - General Requirements [3].

The manufacturer prescribe the safe separation distance based on the fire resistance from the inside resulting from the operating conditions as well as from the inside under the terms of burnout of soot.

This safe separation distance shall be verified according to STN EN 13216-1 or according to an appropriate standard by material. The maximum surface temperature of combustible products can not exceed $100{ }^{\circ} \mathrm{C}$ (under the terms of burnout of soot ) or $85^{\circ} \mathrm{C}$ (at the operating conditions) with the ambient temperature of $20{ }^{\circ} \mathrm{C}$ [1].

If the safety distance is not prescribed in the documentation by the manufacturer, may be determined according to Annex in Decree of Ministry of Interior of the Slovak Republic No. 401/2007 Coll.

\subsection{Safe Separation Distance According to Temperature Class of Appliances}

The minimum clearance is not required for the temperature class $\mathrm{T} 80$, for the maximum surface temperature rise of $52^{\circ} \mathrm{C}$ or for the plastic flue pipes $[3,5]$. According to the German standard DIN $18160-1$ is permissible direct contact to the flue gas temperature of $85^{\circ} \mathrm{C}$ [4]. In the French standard NF DTU 24.1 P1 is for the metal chimney flue pipe with the temperature class of T80 prescribed safe separation distance of $20 \mathrm{~mm}$. For the temperature class T100-T160 it is $40 \mathrm{~mm}$ [6]. This is more benevolent compared with $50 \mathrm{~mm}$ in Decree of Ministry of Interior of the Slovak Republic No. $401 / 2007$ Coll or 50 mm in standard DIN 18 160-1.

There is prescribed minimum separation distance from combustible materials for flue pipes with temperature class above or equal T200. It is the distance of three times the nominal diameter of flue pipe, but minimum 375 $\mathrm{mm}$ for Slovakia and French or $200 \mathrm{~mm}$ for United Kingdom of Great Britain and Northern Ireland [7-10]. For the class T300 is in Slovakia determined the minimum heat resistance $0,22 \mathrm{~m}^{2} . \mathrm{K} / \mathrm{W}$ [5].

The requirement of DIN 18 160-1 at the $400 \mathrm{~mm}$ distance for the flue pipes with temperature class up to T400 is stricker than requirement for the distance of three times the nominal diameter in Slovak regulations only up to the flue pipe diameter $135 \mathrm{~mm}$. For insulated flue pipes is $100 \mathrm{~mm}$ distance allowable. In the Slovak standard STN EN 15287-1 +A1 is except $20 \mathrm{~mm}$ thickness of the insulation defined even a thermal conductivity of 0,04 $\mathrm{W} /(\mathrm{m} . \mathrm{K})[4,5]$. If the manufacturer specifies a different distance, important is that which is indicated in the documentation of the appliance [5].

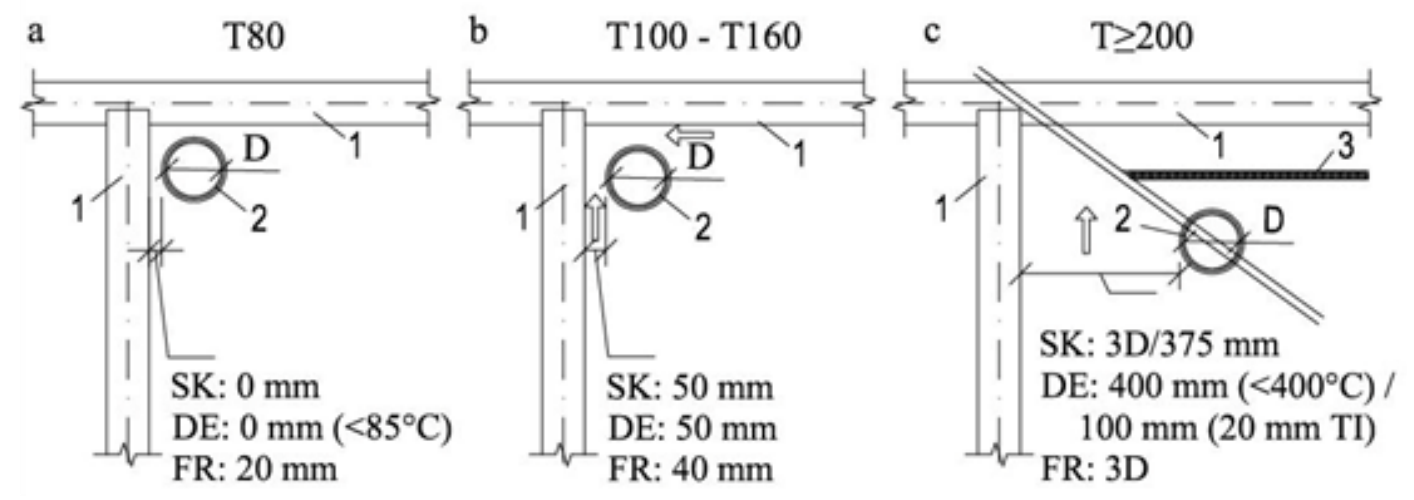

Figure 1. Safe Separation Distances according to Temperature Class, (a) Condensing Appliances; (b) Low-Temperature Flue Gas Appliances; (b) High-Temperature Flue Gas Appliances; 1 - wooden beams; 2 - flue; 3 - non-combustible shield

\subsection{Minimum Allowable Distance}

In Decree of Ministry of Interior of the Slovak Republic No. 401/2007 Coll is generally determined $50 \mathrm{~mm}$ as the safe separation distance or $10 \mathrm{~mm}$ for the insulated gap. In an appendix of this Decree is specified separation distance depending on the connected appliance, which means $800 \mathrm{~mm}$ for solid fuel appliances [3].

In DIN 18160-1 is requirement for safe separation distance in insulated gap more stricter, because there is allowable $20 \mathrm{~mm}$ gap filled with low thermal conductivity insulation [4]. 
Separation distance can be reduced to 1,5 times the diameter of the flue pipe if there is used protection made from non-combustible material between the flue and combustible construction products. In STN EN 15287-1 is it limited by the value of $200 \mathrm{~mm}$ [5]. In the regulations of United Kingdom of Great Britain and Northern Ireland is even prescribed the minimum distance of the protection from protected structures $12,5 \mathrm{~mm}[7,9,10]$.

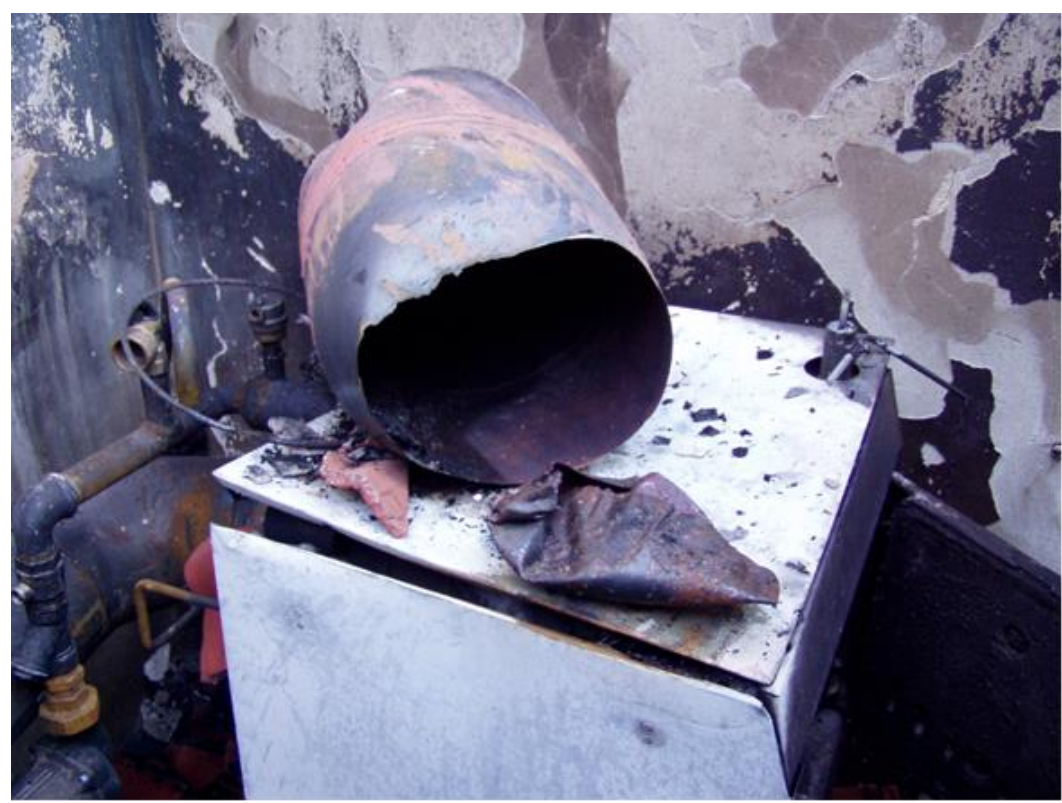

Figure 2. Flue pipe after fire

\section{Summary}

According to statistics of Ministry of Interior of the Slovak Republic are the chimneys and flue pipes still one of the most frequent causes of fire. To reduce the risk of fire because of the flue is necessary to correctly determine the temperature class of connected appliance and to prescribe the safe separation distance of flue from combustible construction parts. The article points out on the differences in the regulations and the need to abolish shortage.

\section{References}

[1] STN EN 1443: Komíny. Všeobecné požiadavky

[2] Information on http://www.minv.sk/?hasici-zachranari

[3] Vyhláška MV SR č. 401/2007 Z.z. o technických podmienkach a požiadavkách na protipožiarnu bezpečnost' pri inštalácii a prevádzkovaní palivového spotrebiča, elektrotepelného spotrebiča a zariadenia ústredného vykurovania a pri výstavbe a používaní komína a dymovodu a o lehotách ich čistenia a vykonávania kontrol

[4] DIN 18 160-1 Abgasanlagen - Planung und Ausführung, ERLUS. [online] [cit. 11-6-2015]. $<$ http://www.erlus.de/downloads/2/141/650/1-5559/erlus_din_18160.pdf>

[5] STN EN 15287-1 +A1: Komíny. Navrhovanie, montáž a prevádzkovanie komínov. Čast' 1: Komíny pre otvorené spotrebiče palív

[6] AFNOR. ceramique.com. [online] 13.3.2006. [cit. 11-6-2015].

$<$ https:/www.google.sk/url?sa=t\&rct=j\&q=\&esrc=s\&source=web\&cd=5\&ved=0CEIQFjAEahUKEwjCy9GryljGAhUBFRQKHb ENAJA\&url=https\%3A\%2F\%2Fwww.ceramique.com\%2Fforum $\% 2$ Fposts\%2FdownloadAttach\%2F516.page\&ei=8_p5VYKGGI GqULGbgIAJ\&usg=AFQjCNHom_B23yvBE_XQPvbmv3v_0oR4OQ\&sig2.>

[7] LABC. Guide to installing solid fuel stoves. Technical guidance for homeowners and trade. carlisle.gov.uk. [online] [cit. 11-62015].<http://www.carlisle.gov.uk/downloads/Guide_to_installing_solid_fuel_stoves.pdf>

[8] Topstak. Regulations. [online] [cit. 11-6-2015]. <http://www.topstak.co.uk/regulations-1/\#backtotop>

[9] Building Regulations 1997. Technical Guidance Document J. Heat Producing Appliances. environ.ie. [online] 2005. [cit. 11-62015]. <http://www.environ.ie/en/Publications/DevelopmentandHousing/BuildingStandards/FileDownLoad,1650,en.pdf>

[10] Combustion appliances - relationship to combustible materials. gov.scot. [online] [cit. 11-6-2015]. $<$ http://www.gov.scot/resource/buildingstandards/2013NonDomestic/chunks/ch04s20.html> 